\title{
Pengaruh Opini Audit dan Temuan Audit BPK terhadap Kinerja Pemerintah Daerah pada Kabupaten/Kota di Provinsi Jawa Timur
}

\author{
Rollis Ayu Ditasari ${ }^{1)}$, M.Agus Sudrajat ${ }^{2)}$ \\ ${ }^{1}$ Prodi D3 Manajemen Pajak, Universitas PGRI Madiun, Indonesia. \\ email: rolisayuditasari@unipma.ac.id \\ ${ }^{2}$ Prodi Akuntansi, Universitas PGRI Madiun, Indonesia. \\ email: agus.sudrajat84@unipma.ac.id
}

\begin{abstract}
This study aims to prove empirically the effect of the Audit Opinion variable and BPK Audit Finding Variables on the Performance of Local Government in districts / cities in East Java Province. This study used purposive sampling with 148 samples obtained from districts / cities in East Java Province. Data testing was performed using: 1) Descriptive statistical test, 2) Classical assumption test, 3) Multiple linear regression and 4) Hypothesis test of the $R$ Determination Coefficient and t test. The researcher processed the research data using special software, namely IBM SPSS Statistics 16. The results of the analysis of this study were 1) Audit Opinion has no effect on the performance of local governments in East Java. This is supported by the tcount value of -1.276 and table of -1.655 so that the tcount value is smaller than the t table value. The significance value is 0.204>0.05, thus $\mathrm{H} 1$ is rejected. 2) BPK Audit findings affect the performance of local governments in East Java. This is supported by the tcount value of -2.267 and the table of -1.655 so that the tcount value is smaller than the table value. The significance value is $0.562<0.05$, thus $\mathrm{H} 2$ is accepted.
\end{abstract}

Keyword: Audit Opinion, BPK Audit Findings and East Java Regional Government Performance.

\begin{abstract}
Abstrak
Penelitian ini bertujuan untuk membuktikan secara empiris pengaruh yang ditimbulkan oleh variabel Opini Audit dan Variabel Temuan Audit BPK terhadap Kinerja Pemerintah Daerah Pada kabupaten/kota di Provinsi Jawa Timur. Penelitian ini menggunakan purposive sampling dengan 148 sampel yang diperoleh dari kabupaten / kota di Provinsi Jawa Timur. pengujian data dilakukan dengan menggunakan : 1) Uji statistik deskriptif, 2) Uji asumsi klasik, 3) Regresi linear berganda dan 4) Uji hipotesis Koefisien Determinasi R dan Uji t. Peneliti mengolah data penelitian menggunakan bantuan software khusus, yakni IBM SPSS Statistics 16. Hasil dari analisa penelitian ini adalah 1)Opini Audit tidak berpengaruh terhadap kinerja pemerintah daerah di Jawa Timur. Hal ini didukung dengan nilai $t_{\text {hitung }}$ sebesar $-1,276$ dan $t_{\text {tabel }}$ sebesar -1,655 sehingga nilai $t_{\text {hitung }}$ lebih kecil dari nilai $t_{\text {tabel }}$. Nilai signifikasinya sebesar 0,204 >0,05 dengan demikian $\mathrm{H}_{1}$ ditolak. 2)Temuan Audit BPK berpengaruh terhadap kinerja pemerintah daerah di Jawa Timur. Hal ini didukung dengan nilai $t_{\text {hitung }}$ sebesar -2,267 dan $t_{\text {tabel }}$ sebesar 1,655 sehingga nilai $t_{\text {hitung }}$ lebih kecil dari nilai $t_{\text {tabel }}$. Nilai signifikasinya sebesar $0,562<0,05$ dengan demikian $\mathrm{H}_{2}$ diterima.
\end{abstract}

Kata Kunci: Opini Audit, Temuan Audit BPK dan Kinerja Pemerintah Daerah Jawa Timur.

\section{PENDAHULUAN}

Kebijakan mengenai otonomi daerah di Indonesia mulai berlaku sejak tahun 1999 setelah terjadi gejolak sosial di beberapa tahun sebelumnya. Otonomi Daerah dalam Undang-Undang Republik Indonesia Nomor 23 Tahun 2014 Tentang Pemerintahan Daerah memiliki arti daerah otonom berhak, berkewajiban, dan mempunyai wewenang untuk mengatur serta mengurus kepentingan masyarakat setempat dan mengurus urusan pemerintahan sendiri sesuai sistem Negara Kesatuan Republik Indonesia. Pemerintah daerah diharap dapat menjadikan daerahnya semakin mandiri, dan mampu membiayai pembangunan di daerahnya dengan adanya pengurangan campur tangan dari pemerintah pusat pada pengelolaan keuangan daerah.

Tercapai tidaknya kemajuan dari organisasi dapat dilakukan dengan cara melakukan pengukuran kinerja. Menurut Mardiasmo (2009:121), maksud dari pengukuran kinerja sektor publik adalah untuk : 1) Memperbaiki kinerja pemerintah yang artinya membantu pemerintah untuk fokus pada sasaran serta tujuan program dari unit kerja, 2) Digunakan untuk mengalokasikan sumber daya yang ada dan sebagai bahan pertimbangan dalam pengambilan keputusan, dan 3) Mewujudkan akuntabilitas publik dan juga sebagai pemerbaik komunikasi dalam lembaga. Harapan dari adanya pengukuran kinerja ialah agar dapat mencapai target 
kinerja dengan cara monitoring dan evaluasi hasil. Pencapaian kinerja nantinya akan menimbulkan penghargaan maupun hukuman, sehingga arahan untuk mencapai target sangat diperlukan (Mardiasmo, 2009:121).

Peringatan Hari Otonomi Daerah ke-22 tahun 2018 Kemendagri melakukan Evaluasi Kinerja Penyelenggaraan Pemerintah Daerah (EKPD) 2017. EKPD tersebut berdasarkan Laporan Penyelenggaraan Pemerintah Daerah (LPPD) tahun 2016. Kemendagri menetapkan tiga provinsi, sepuluh provinsi, dan sepuluh kabupaten dan kota berprestasi kinerja tinggi secara nasional. Tiga provinsi di Indonesia yang menerima penghargaan yakni provinsi : Jawa Timur, Jawa Barat dan Jawa Tengah. Pemerintah daerah kabupaten berprestasi sepuluh besar kinerja tinggi diduduki oleh kabupaten: Sidoarjo, Tulungagung, Karanganyar, Banyuwangi, Malang, Pasuruan, Kuningan, Kudus, Bulukumba dan Bone. Pemerintah daerah kota berprestasi sepuluh besar kinerja tinggi diduduki oleh kota : Malang, Makassar, Surabaya, Blitar, Gorontalo, Semarang, Bandung, Tangerang, Samarinda dan Parepare (Nadlir, 2018).

Untuk mewujudkan penyelenggaraan pemerintah yang baik, maka dalam melakukan pengelolaan keuangan harus dengan baik, akuntabel dan transparan. Pengelolaan keuangan daerah merupakan bagian penting dalam penyusunan Laporan Penyelenggaraan Pemerintah Daerah (LPPD) suatu pemerintah daerah, oleh karena itu perlu dilakukan pemeriksaan dan pengawasan (audit) yang baik oleh Badan Pemeriksa Keuangan (BPK). Hasil pemeriksaan yang dilakukan oleh BPK salah satunya berupa temuan audit. Adapun tujuan dalam penelitian ini yang hendak dicapai adalah untuk membuktikan secara empiris penilaian kinerja pemerintah daerah Kabupaten/Kota di Jawa Timur berdasarkan Opini Audit dan Temuan Audit BPK.

\section{KAJIAN TEORI DAN PENGEMBANGAN HIPOTESA Teori Keagenan (Agency Theory)}

Berdasarkan Penelitian Halim dan Abdullah (2015) menjelaskan bahwa teori keagenan (Agency Theory) merupakan teori yang menganalisis susunan kontraktual antara dua atau bahkan bisa lebih organisasi, individu ataupun kelompok, yang menjelaskan hubungan agen dan prinsipal. Dengan harapan pihak lain (agen) melakukan/melaksanakan pekerjaan dengan baik seperti yang diinginkan oleh salah satu pihak (prinsipal). Penerapan teori keagenan juga dapat dilakukan pada sector public. Dalam negara demokrasi mempunyai hubungan keagenan antara masyarakat dengan pemerintah atau hubungan antara pemerintah daerah dengan pemerintah pusat. Dalam hal ini pemerintah daerah memiliki tanggung jawab terhadap pemerintah pusat yang telah memberikan wewenang kepada pemerintah daerah untuk mengelola pemerintahan daerah secara mandiri. Selain itu pemerintah daerah juga harus bertanggung jawab dalam memaksimalkan kesejahteraan masyarakat (Zelmiyanti 2016:12).

\section{Opini Audit}

Opini merupakan salah satu kategori laporan keuangan pemerintah daerah. Definisi opini menurut Undang-Undang No. 15 Tahun 2004 ialah : "Pernyataan profesional sebagai kesimpulan pemeriksa mengenai tingkat kewajaran informasi yang disajikan dalam laporan keuangan". Audit kinerja pemerintah adalah pengaturan kelembagaan yang penting di bawah struktur pemerintahan pemerintah (Fan, 2012:101). Opini audit menambah kredibilitas dan nilai informasi laporan keuangan yang diberikan kepada publik (Samarinas, 2016:21).

Menurut Moalla (2019:104), Opini audit diklasifikasikan dalam empat kategori, yaitu : 1) opini wajar tanpa pengecualian (opini bersih), 2) tidak memenuhi syarat dengan paragraf penjelasan, 3) opini audit yang berkualitas (dengan atau tanpa paragraf penjelasan) dan 4) opini going concern. Opini audit menurut Agoes (2014:75) terbagi atas :

a. Wajar Tanpa Pengecualian (WTP) 
Laporan keuangan disajikan secara wajar sesuai standar. Opini ini menjadi opini terbaik yang dikeluarkan oleh auditor.

b. Wajar Tanpa Pengecualian Dengan Paragraf Penjelas (WTP-DPP)

Auditor menambahkan paragraf penjelas pada laporan keuangan yang diaudit dalam keadaan tertentu.

c. Wajar Dengan Pengecualian (WDP)

Laporan keuangan disajikan secara wajar baik, kecuali dampak hal yang berkaitan dengan yang dikecualikan.

d. Tidak Wajar

Auditor menyatakan bahwa laporan keuangan disajikan tidak secara wajar sehingga tidak sesuai standar.

e. Tidak Memberikan Pendapat

Auditor tidak menyatakan pendapatnya apabila tidak dapat merumuskan kewajaran laporan keuangan sesuai standar. Opini ini menjadi opini terburuk yang dikeluarkan oleh auditor.

\section{Temuan Audit BPK}

Menurut Hendriyani Dan Tahar (2015:27) menyatakan bahwa temuan audit merupakan temuan oleh BPK terhadap kasus-kasus pada laporan keuangan berupa ketidaksesuaian dan kerancuan dengan realisasi laporan serta teridentifikasi sebagai suatu pelanggaran. Dalam UU No.15 tahun 2004 Badan Pemeriksa Keuangan (BPK) adalah Badan Pemeriksa Keuangan sebagaimana dimaksud dalam Undang Undang Dasar Negara Republik Indonesia Tahun 1945.

Pemeriksaan keuangan negara meliputi pemeriksaan atas pengelolaan keuangan negara dan pemeriksaan atas tanggung jawab keuangan negara. Pemeriksaan adalah proses identifikasi masalah, analisis, dan evaluasi yang dilakukan secara independen, objektif, dan profesional berdasarkan standar pemeriksaan, untuk menilai kebenaran, kecermatan, kredibilitas, dan keandalan informasi mengenai pengelolaan dan tanggung jawab keuangan negara. Pemeriksaan keuangan negara dilakukan oleh Badan Pemeriksa Keuangan (BPK) dan terdiri dari pemeriksaan keuangan, pemeriksaan kinerja dan pemeriksaan dengan tujuan tertentu. Hasil dari pemeriksaan yang dilakukan BPK tersebut berupa, opini, temuan, kesimpulan atau dalam bentuk rekomendasi.

Mustikarini dan Fitriasasi (2012:7) menyimpulkan adanya hubungan antara pengukuran kinerja Pemda dan sistem pengawasan, termasuk audit kinerja dan evaluasi program. Semakin banyak pelanggaran yang dilakukan oleh Pemda menggambarkan semakin buruknya kinerja Pemda tersebut.

\section{Kinerja Pemerintah Daerah}

Pengelolaan Keuangan Daerah diatur oleh Undang-Undang Nomor 23 tahun 2014 Peraturan Pemerintah (PP) Nomor 12 Tahun 2019. Selanjutnya ketentuan Pasal 293 dan Pasal 330 Undang-Undang Nomor 23 Tahun 2014 tentang Pemerintahan Daerah memberikan amanat untuk mengatur Pengelolaan Keuangan Daerah dengan sebuah Peraturan Pemerintah. Sebagaimana kita ketahui bahwa Pengelolaan Keuangan Daerah adalah keseluruhan kegiatan yang meliputi perencanaan, penganggaran, pelaksanaan, penatausahaan, pelaporan, pertanggungjawaban, dan pengawasan Keuangan Daerah. Keuangan Daerah adalah semua hak dan kewajiban Daerah dalam rangka penyelenggaraan Pemerintahan Daerah yang dapat dinilai dengan uang serta segala bentuk kekayaan yang dapat dijadikan milik Daerah berhubung dengan hak dan kewajiban Daerah tersebut. Keuangan Daerah selain diatur dengan Peraturan Pemerintah juga mengikuti Peraturan Menteri dan keuangan daerah juga mengikuti Undang- 
Undang Anggaran Pendapatan dan Belanja Negara yang ditetapkan setiap tahun, dan Anggaran Pendapatan dan Belanja Daerah masing-masing daerah yang disinkronkan dan dikelola secara sistematis.

Liu dan Raine (2016, dalam Cheung, 2019:48) berpendapat bahwa kinerja pemerintah merupakan faktor signifikan yang mempengaruhi kepercayaan politik. Di negara China, peringkat kinerja ekonomi pemerintah daerah menggunakan pendekatan kuantitatif terpadu (DEA) dan kualitatif (AHP) (Lin, 2010:129). Kinerja adalah suatu tingkat pencapaian pelaksanaan kegiatan, kebijakan dan program untuk mewujudkan sasaran, visi misi dan tujuan organisasi yang ada dalam perumusan perencanaan strategis (strategic planning) organisasi (Soleh dan Suripto, 2011: 3). Pengukuran kinerja digunakan dalam pengambilan keputusan organisasi untuk meningkatkan kinerja (Poister et al., 2014 dalam Roh, 2018:267). Fryer et al. dalam Roh, 2018:267) menunjukkan empat tahap pengukuran kinerja : 1) memutuskan apa yang harus diukur, 2) memutuskan bagaimana mengukur kinerja, 3) menggunakan atau menginterpretasikan data yang dihasilkan, dan 4) mengkomunikasikan hasilnya. Beberapa indikator kinerja menurut Janjua et al. (2018) yaitu : 1) pemberian layanan kepada warga seperti termasuk memeriksa kehadiran staf, memeriksa fasilitas pendidikan, pemantauan layanan kota dan memeriksa fungsi pengaturan, dan 2) pemanfaatan yang efektif dari hibah anggaran provinsi yang dikembangkan menggunakan model penganggaran berbasis hasil.

\section{Pengembangan Hipotesis}

1. Pengaruh Opini Audit Terhadap Kinerja Pemerintah Daerah Kabupaten/Kota di Jawa Timur

Opini adalah suatu pernyataan profesional oleh pihak berwenang sebagai kesimpulan dari pemeriksaan keuangan pada laporan keuangan. Opini menunjukkan tingkat kewajaran informasi, sehingga dapat menjadi indikator (tolok ukur) untuk menilai akuntabilitas pemerintah. Tingkat kepercayaan atas pelaporan keuangan yang disajikan untuk pemangku kepentingan juga dipengaruhi oleh opini audit. Didukung oleh penelitian yang dilakukan Suryaningsih (2016:1475) menyatakan bahwa opini audit BPK berpengaruh pada kinerja pemerintah daerah sebab Hasil penelitian yang sama dilakukan oleh Masdiantini (2016:1177) yang menyatakan bahwa terdapat pengaruh positif signifikan antara opini audit BPK dengan kinerja keuangan pemerintah Kabupaten/Kota Se-Bali. Berdasarkan uraian diatas, peneliti merumuskan hipotesis pertama :

\section{$H_{1}$ : Opini Audit Berpengaruh Terhadap Kinerja Pemerintah Daerah Kabupaten/Kota di Jawa Timur.}

\section{Pengaruh temuan audit BPK terhadap kinerja pemerintah daerah.}

Menurut penelitian oleh Afrian Galang (2016:1042) menyatakan bahwa temuan BPK audit merupakan kumpulan kasus-kasus yang ditemukan oleh BPK pada laporan keuangan pemerintah daerah atas suatu pelanggaran yang dilakukan suatu daerah terhadap perundang-undangan yang berlaku. Dengan adanya temuan ini BPK meminta agar adanya peningkatan koreksi dan pemeriksaan. Dengan begitu, semakin besar jumlah temuan BPK maka kinerja pemerintah daerah dinilai semakin rendah.

Hal ini sejalan dengan penelitian yang dilakukan oleh Mustikarini dan Fitriasari (2012:7), bahwa semakin banyak jumlah temuan audit BPK maka semakin rendah kinerja pemda itu dinilai. Berdasarkan Uraian diatas, Peneliti Merumuskan Hipotesis Kedua : 


\section{$H_{2}$ : Temuan audit BPK berpengaruh terhadap kinerja pemerintah daerah kabupaten/kota di Provinsi Jawa Timur.}

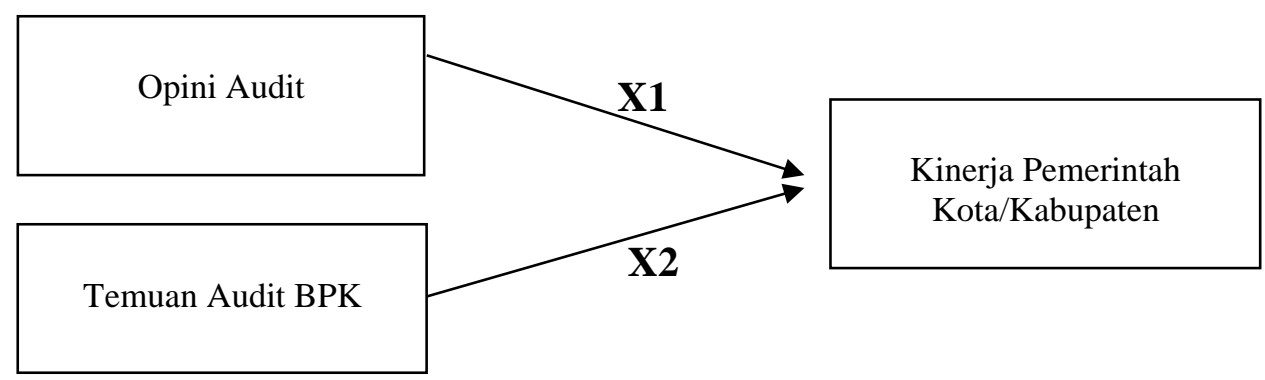

Gambar 1 Kerangka Konseptual

\section{METODE PENELITIAN}

\section{Sumber Data}

Penelitian ini dilakukan di Direktorat Jenderal Perimbangan Keuangan (DJPK) Kementrian Keuangan di situs resminya di :

1. www.djpk.kemenkeu.go.id

2. Kementerian Dalam Negeri di situs resminya www.kemendagri.go.id

3. Badan Pusat Satistik Provinsi Jawa Timur di situs resminya https://jatim.bps.go.id

4. BPK Perwakilan Provinsi Jawa Timur di situs resminya www.surabaya.bpk.go.id dan melalui e-mail.

Penelitian ini merupakan jenis penelitian dengan metode kuantitatif yang berlandaskan filsafat positivisme (Sugiyono, 2017:8).

Pendefinisian populasi menurut Sugiyono (2017:80) adalah wilayah generalisasi yang terdiri atas subjek/objek yang mana peneliti menerapkan karakteristik dan kualitas tertentu untuk dipelajari dan nantinya akan digunakan dalam penarikan kesimpulan. Sesuai dengan judul peneliti, maka penelitian ini menggunakan populasi seluruh Kabupaten/Kota di Jawa Timur tahun 2014-2017.

Sampel adalah bagian dari jumlah dan karakteristik populasi yang digunakan (Sugiyono, 2017:81). Penelitian ini memiliki jumlah sampel sebanyak 37 Kabupaten/Kota di Jawa Timur yang memiliki data lengkap yang diperlukan peneliti dalam kurun waktu 4 tahun (2014-2017). Sampel penelitian memiliki kriteri sebagai berikut :

Tabel 3.2. Penentuan Sampel Penelitian

\begin{tabular}{|c|l|c|}
\hline No & \multicolumn{1}{|c|}{ Kriteria Penentuan Sampel } & Jumlah Amatan \\
\hline 1 & Jumlah Kabupaten/Kota di Jawa Timur & 38 \\
\hline 2 & $\begin{array}{l}\text { Kabupaten/Kota yang tidak memiliki } \\
\text { kelengkapan data yang dibutuhkan }\end{array}$ & $(1)$ \\
\hline 3 & Jumlah Sampel & 37 \\
\hline \multicolumn{2}{|c|}{ Total Sampel selama 4 tahun (2014-2017) } \\
\hline
\end{tabular}

Sampel dalam penelitian ini mengecualikan Kota Pasuruan, karena BPK Perwakilan Jawa Timur menyatakan bahwa Neraca dalam Laporan Keuangan Pemerintah Daerah (LKPD) Kota 
Pasuruan tahun 2017 merupakan informasi publik yang dikecualikan sehingga tidak dapat diungkapkan kepada masyarakat umum.

Teknik sampling merupakan teknik pengambilan sampel (Sugiyono, 2017:81). Pengambilan sampel dalam penelitian ini menggunakan teknik nonprobability sampling, yakni dengan teknik sampling purposive. Definisi dari teknik nonprobability sampling ialah suatu teknik pengambilan sampel yangmana tidak memberi kesempatan/peluang sama bagi setiap anggota populasi untuk dijadikan sampel (Sugiyono (2017:84). Menurut Sugiono (2017:85), sampling purposive memiliki artian bahwa sampel penelitian ditentukan dengan menggunakan pertimbangan tertentu.

\section{Definisi Operasional Variabel dan Pengukuran Variabel Kinerja Pemerintah Daerah (Y)}

Kinerja pemerintah daerah adalah pencapaian atas penyelenggaraan urusan pemerintahan daerah yang pengukurannya dilihat dari masukan, proses, keluaran, hasil, manfaat, dan dampak (Peraturan Pemerintah Nomor 6 Tahun 2008 pasal 1 ayat 12). Maksud dari pengukuran kinerja : 1) membantu perbaikan kinerja pemerintah agar sesuai tujuan, 2) mengalokasikan sumber daya sebagai dasar pembuatan keputusan, dan 3) membantu mewujudkan tanggung jawab publik serta memperbaiki komunikasi (Mardiasmo, 2009:121).

Variabel kinerja pemerintah daerah menggunakan skala nominal. Kinerja pemerintah daerah diukur berdasarkan nilai Skor SKPPD (Status Kinerja Penyelenggaraan Pemerintahan Daerah) secara nasional. Kinerja pemerintah daerah dalam penelitian ini memiliki rumus :

$$
\text { Kinerja pemerintah daerah }=\text { Skor SKPPD }
$$

\section{Opini Audit (X1)}

Opini audit adalah pernyataan profesional tentang tingkat kewajaran informasi dalam penyajian laporan keuangan sebagai kesimpulan pemeriksaan (Undang-Undang No. 15 Tahun 2004 pasal 1 ayat 11).

Variabel opini audit menggunakan skala ordinal. Opini audit diukur berdasarkan hasil opini BPK dengan cara memberi nilai 1 untuk opini Tidak Memberikan Pendapat, nilai 2 untuk opini Tidak Wajar, nilai 3 untuk opini Wajar Dengan Pengecualian (WDP), nilai 4 untuk opini Wajar Tanpa Pengecualian Dengan Paragraf Penjelas (WTP-DPP), dan nilai 5 untuk opini Wajar Tanpa Pengecualian (WTP).

\section{Temuan Audit BPK ( $\left.\mathbf{X}_{2}\right)$}

Pada penelitian Mustikarini dan Fitriasasi (2012:8), temuan audit BPK diukur dengan temuan audit (dalam rupiah) dibandingkan dengan total anggaran belanja. Dengan demikian variabel temuan audit BPK penelitian ini menggunakan rumus :

$$
\text { Temuan audit }=\frac{\text { Temuan audit }(\text { dalam rupiah })}{\text { Total anggaran belanja }}
$$

\section{Teknik Pengumpulan Data}


Berdasarkan sumber pemerolehan data, data yang digunakan dalam penelitian ini adalah data sekunder. Definisi sumber data sekunder menurut Sugiyono (2017:137) adalah pengguna data tidak menerima data dari sumber langsung, melainkan melalui orang lain maupun melalui dokumen. Data sekunder dalam penelitian ini diperoleh dari:

1. Studi pustaka. Peneliti mengambil data sebagai pendahuluan, landasan teori dan penelitian terdahulu yang diperoleh dari jurnal, skripsi, artikel, buku serta sumber tertulis lainnya yang sesuai dengan topik penelitian.

2. Studi dokumentasi. Peneliti mengumpulkan data sekunder, mencatat, dan mengolah data yang berkaitan dengan penelitian. Adapun sumber dokumentasi yang digunakan yakni :

a. Data realisasi APBD untuk memperoleh data total pendapatan, pendapatan asli daerah (PAD) dan dana perimbangan. Sedangkan sebagian data neraca untuk memperoleh data total aset, total hutang dan total ekuitas dari Direktorat Jenderal Perimbangan Keuangan Kementrian Keuangan di situs resminya www.djpk.kemenkeu.go.id.

b. Data jumlah anggota DPR yang diperoleh dari Badan Pusat Satistik Provinsi Jawa Timur melalui situs resminya https://jatim.bps.go.id.

c. Data opini audit dan sebagian data neraca diperoleh dari BPK Perwakilan Provinsi Jawa Timur melalui situs resminya di www.surabaya.bpk.go.id dan melaui $e$-mail.

d. Data skor Status Kinerja Penyelenggaraan Pemerintah Daerah (SKPPD) melalui Keputusan Menteri Dalam Negeri melalui situs resmi Kementerian Dalam Negeri di www.kemendagri.go.id.

\section{HASIL DAN PEMBAHASAN \\ Gambaran Umum}

Penelitian ini menggunakan objek pemerintah Kabupaten/Kota di Jawa Timur pada tahun 2014-2017. Jumlah sampel yang digunakan sebanyak 37 Kabupaten/Kota di Jawa Timur dalam kurun waktu 4 tahun (2014-2017) sehingga total data sampel sebayak 148. Teknik pengambilan sampel yakni dengan sampling purposive, yang memiliki artian bahwa sampel penelitian ditentukan dengan menggunakan pertimbangan tertentu. Kriteria pengambilan sampel didasarkan pada kelengkapan data Kabupaten/Kota sesuai yang diperlukan peneliti.

Data yang digunakan dalam penelitian adalah data realisasi APBD untuk memperoleh data total pendapatan, pendapatan asli daerah (PAD) dan dana perimbangan. Data neraca untuk memperoleh data total aset, total hutang dan total ekuitas. Data jumlah anggota DPR, data opini audit, dan data skor Status Kinerja Penyelenggaraan Pemerintah Daerah.

\section{Statistik Deskriptif}

Jumlah pengamatan $(\mathrm{N})$ dari penelitian ini sebanyak 148 data sampel. Nilai maksimum, nilai minimum, nilai rata-rata, dan standar deviasi dari masing-masing variabel ditunjukkan oleh hasil uji statistik deskriptif. Berikut ini adalah hasil dari pengujian statistik deskriptif :

Tabel 4.1. Hasil Uji Statistik deskriptif 
INVENTORY : Jurnal Akuntansi Vol. 4 No. 2 Oktober 2020

\begin{tabular}{lcrrrr}
\hline & N & Minimum & Maximum & \multicolumn{1}{c}{ Mean } & Std. Deviation \\
\hline Opini Audit & 148 & 3.00 & 5.00 & 4.4189 & .81661 \\
Temuan Audit BPK & 148 & .00 & .01 & .0004 & .00106 \\
Kinerja Pemda & 148 & 2.58 & 3.59 & 3.1734 & .20003 \\
Valid N (listwise) & 148 & & & & \\
\hline
\end{tabular}

Sumber : data diolah, 2020

Variabel opini audit mempunyai nilai minimum sebesar 3, nilai maksimum sebesar 5 dan nilai rata-rata sebesar 4,4189. Nilai standar deviasi sebesar 0,81661 lebih kecil dari nilai rata-rata sehingga sebaran data tidak memiliki kesenjangan yang besar. Hal tersebut menunjukkan bahwa data yang digunakan dalam variabel ukuran pemerintah daerah adalah stabil.

Variabel Temuan Audit BPK mempunyai nilai minimum sebesar 0,00 dimiliki oleh Kabupaten Jombang pada tahun 2017, nilai maksimum sebesar 0,01 dimiliki oleh Kabupaten Sidoarjo dan Kabupaten Tulungagung, dan nilai rata-rata sebesar 0,0004. Nilai standar deviasi sebesar 0,00106 lebih kecil dari nilai rata-rata sehingga sebaran data tidak memiliki kesenjangan yang besar. Hal tersebut menunjukkan bahwa data yang digunakan dalam variabel ukuran pemerintah daerah adalah stabil.

Variabel kinerja pemerintah daerah mempunyai nilai minimum sebesar 2,58 dimiliki oleh Kabupaten Jombang pada tahun 2017, nilai maksimum sebesar 3,59 dimiliki oleh Kabupaten Sidoarjo dan Kabupaten Tulungagung, dan nilai rata-rata sebesar 3,1734. Nilai standar deviasi sebesar 0,20003 lebih kecil dari nilai rata-rata sehingga sebaran data tidak memiliki kesenjangan yang besar. Hal tersebut menunjukkan bahwa data yang digunakan dalam variabel ukuran pemerintah daerah adalah stabil.

\section{HASIL PENGUJIAN HIPOTESIS}

\section{Uji Asumsi klasik}

Uji asumsi klasik digunakan untuk memenuhi tahapan dalam pengujian regresi linear berganda. Uji asumsi klasik terdiri atas empat pengujian, yakni : 1) Uji Normalitas, 2) Uji Autokorelasi, 3) Uji Multikolonieritas, dan 4) Uji Heteroskedastisitas.

\section{a. Uji Normalitas Data}

Uji normalitas merupakan pengujian untuk mengetahui apakah variabel pengganggu atau residual terdistribusi secara normal atau tidak. Model regresi dikatakan baik apabila mempunyai hasil distribusi secara normal. Uji normalitas dalam penelitian ini dilakukan dengan menggunakan uji statistik non-parametrik One Sample KolmogorovSmirnov (K-S), dikatakan terdistribusi secara normal apabila nilai koefisien Asymp. Sig. (2-tailed) lebih besar dari taraf signifikansi $(\alpha=0,05)$. Berikut ini adalah hasil dari pengujian uji normalitas Kolmogorov-Smirnov : 
Tabel 4.2. Hasil Uji Normalitas

\begin{tabular}{|c|c|c|}
\hline \multicolumn{2}{|l|}{$\begin{array}{c}\text { One-Sample Kolmogorov- } \\
\text { Smirnov Test } \\
\end{array}$} & \multirow{2}{*}{$\begin{array}{r}\begin{array}{c}\text { Unstandardized } \\
\text { Residual }\end{array} \\
148\end{array}$} \\
\hline $\mathrm{N}$ & & \\
\hline \multirow[t]{2}{*}{ Normal Parameters $^{\mathrm{a}}$} & Mean & .0000000 \\
\hline & Std. Deviation & .19561081 \\
\hline \multirow[t]{3}{*}{ Most Extreme Differences } & Absolute & .098 \\
\hline & Positive & .035 \\
\hline & Negative & -.098 \\
\hline Kolmogorov-Smirnov Z & & 1.190 \\
\hline Asymp. Sig. (2-tailed) & & .118 \\
\hline
\end{tabular}

Sumber : data diolah, 2020

Berdasarkan tabel 4.2. dapat diketahui bahwa nilai Asymp. Sig. (2-tailed) adalah sebesar 0,118. Nilai tersebut menunjukkan probabilitas penerimaan 0,118 lebih besar dari taraf signifikansi 0,05 $(0,118>0,05)$, dengan demikian dapat disimpulkan bahwa data yang digunakan dalam penelitian ini terdistribusi secara normal.

b. Uji Autokorelasi

Uji autokorelasi merupakan pengujian untuk mengetahui korelasi antara kesalahan pengganggu pada periode $t$ dengan kesalahan pengganggu pada periode sebelumnya dalam model regresi linear. Model regresi yang baik berupa bebasnya regresi dari autokorelasi. Untuk mendeteksi ada tidaknya autokorelasi, maka dalam penelitian ini digunakanlah uji Durbin-Watson. Berikut ini adalah hasil dari pengujian Durbin-Watson

Tabel 4.3. Hasil Uji Autokorelasi

\begin{tabular}{|c|c|c|c|c|c|}
\hline Model & $\mathbf{R}$ & R Square & $\begin{array}{c}\text { Adjusted R } \\
\text { Square }\end{array}$ & $\begin{array}{l}\text { Std. Error of } \\
\text { the Estimate }\end{array}$ & Durbin-Watson \\
\hline 1 & $.209^{\mathrm{a}}$ & .044 & .031 & .19696 & 1.813 \\
\hline
\end{tabular}

Sumber : data diolah, 2020

Berdasarkan tabel 4.3. menunjukkan bahwa nilai Durbin-Watson sebesar 1,813. Nilai tabel Durbin-Watson dengan nilai signifikansi 5\%, dengan jumlah sampel $n=148$ dan jumlah variabel independen $\mathrm{k}=2$, maka diperoleh nilai sebagai berikut.

$\mathrm{dL}=1,7041$ dan $\mathrm{du}=1,7588$. Diperoleh nilai Durbin-Watson sebesar 1,813 yang lebih besar dari 1,7588 dan lebih kecil dari 4-du $(4-1,7588=2,2412)$, dengan demikian dapat disimpulkan bahwa tidak terdapat autokorelasi.

\section{c. Uji Multikoleniaritas}

Uji multikolonieritas merupakan pengujian untuk mengetahui apakah dalam model regresi ditemukan adanya korelasi (hubungan) antar variabel independen. Model regresi yang baik adalah yang tidak terjadi hubungan antar variabel independen. Uji multikolonieritas dilakukan dengan melihat angka Collinearity Statistics yang ditunjukkan oleh nilai Tolerance dan nilai VIF. Apabila nilai Tolerance $\geq 0,10$ dan VIF $\leq 10$ maka tidak 
terjadi multikolinieritas dan sebaliknya, apabila nilai Tolerance $\leq 0,10$ dan VIF $\geq 10$ maka terjadi multikolinieritas. Berikut ini adalah hasil dari pengujian Tolerance dan VIF :

Tabel 4.4. Hasil Uji Multikolonieritas

\begin{tabular}{llcr}
\hline & & \multicolumn{2}{c}{ Collinearity Statistics } \\
& Model & Tolerance & VIF \\
\hline 1 & (Constant) & & \\
Opini Audit & .999 & 1.001 \\
Temuan & & \\
Audit & .999 & 1.001 \\
\hline & Sumber : data diolah, 2020
\end{tabular}

Berdasarkan tabel 4.4. dihasilkan nilai Tolerance diatas lebih dari 0,1 sebesar 0,999 pada seluruh variable yang diuji. Dengan demikian berdasarkan nilai Tolerance maka dapat disimpulkan tidak terdapat multikoleniaritas pada model yang digunakan dalam penelitian ini.

Nilai VIF dari masing-masing variabel bebas (Opini Audit dan Temuan Audit BPK) yang dihasilkan kurang dari 10 pada seluruh variable penelitian sehingga berdasarkan nilai VIF dapat disimpulkan bahwa pada model yang digunakan dalam penelitian ini tidak mengandung multikolinearitas. Hal ini semakin menguatkan bahwa model yang digunakan dalam penelitian ini benar-benar bebas dari multikolinearitas.

\section{d. Uji Heteroskedastisitas}

Uji Heteroskedastisitas merupakan pengujian untuk mengetahui apakah dalam model regresi terjadi ketidaksamaan varience dari residual suatu pengamatan ke pengamatan yang lain. Model regresi yang baik berbentuk homoskedastisitas atau tidak terjadi heteroskedastisitas.

Tabel 4.5. Hasil Uji Heteroskedastisitas

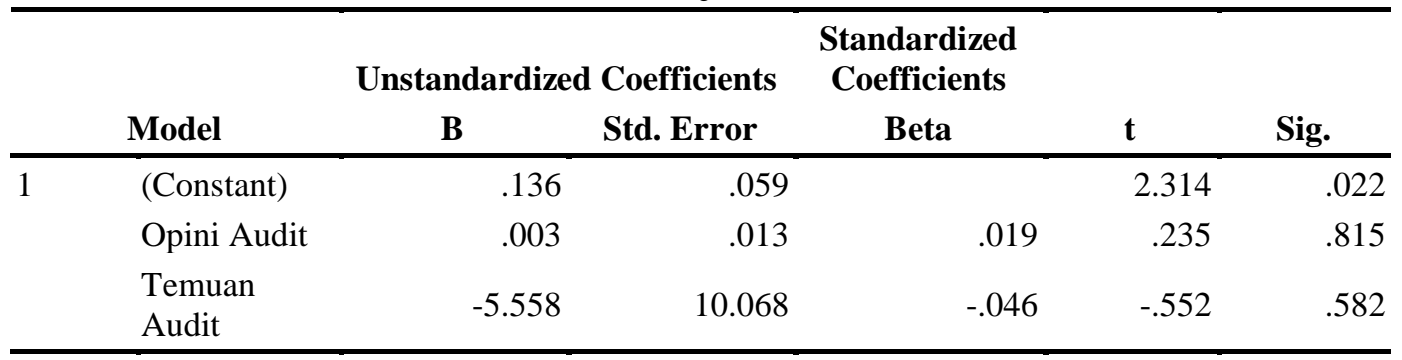

a. Dependent Variable: ABS_RES

Sumber : data diolah, 2020

Berdasarkan Tabel 4.5 hasil uji heteroskedastisitas yang dilakukan dengan menggunakan uji gletser,diketahui bahwa variabel opini audit dan Temuan audit BPK memiliki nilai signifikansi t lebih besar dari 0,05 sehingga dapat disimpulkan bahwa model regresi terbebas dari heteroskedastisitas.

\section{Pengujian Hipotesis}

\section{a. Koefisien Determinasi $\left(\mathbf{R}^{2}\right)$}


Koefisien determinasi $\left(\mathrm{R}^{2}\right)$ merupakan pengujian untuk mengetahui seberapa jauh kemampuan model dalam menerangkan variasi variabel dependen. apabila nilai Adjusted $R$ Square mendekati satu, maka variabel independen memberikan sebagian besar informasi yang dibutuhkan. Berikut ini adalah hasil dari pengujian koefisien determinasi $\left(\mathrm{R}^{2}\right)$ :

Tabel 4.6. Hasil Uji Koefisien Determinasi

\begin{tabular}{|c|c|c|c|c|c|}
\hline Model & $\mathbf{R}$ & R Square & $\begin{array}{l}\text { Adjusted R } \\
\text { Square }\end{array}$ & $\begin{array}{l}\text { Std. Error of } \\
\text { the Estimate }\end{array}$ & Durbin-Watson \\
\hline 1 & $209^{\mathrm{a}}$ & .044 & .031 & .19696 & 1.813 \\
\hline
\end{tabular}

Berdasarkan tabel 4.6. diatas, dapat dilihat bahwa Adjusted $R$ Square memiliki nilai sebesar 0,031. Hal tersebut berarti bahwa prosentase variabel independen (opini audit) yang berpengaruh terhadap variabel dependen (kinerja pemerintah daerah) sebesar 3,1\%. Kemudian sisanya, sebesar 96,9\% dijelaskan oleh variabel lain di luar variabel penelitian.

\section{b. Uji Statistik t}

Uji Statistik t merupakan pengujian untuk mengetahui seberapa jauh pengaruh suatu variabel independen secara individual dalam menerangkan variabel dependen. Berikut ini adalah hasil dari pengujian uji statistik $\mathrm{t}$ :

Tabel 4.7. Hasil Uji Statistik t

\begin{tabular}{|c|c|c|c|c|c|c|}
\hline & \multirow[b]{2}{*}{ Model } & \multicolumn{2}{|c|}{ Unstandardized Coefficients } & \multirow{2}{*}{$\begin{array}{c}\text { Standardized } \\
\text { Coefficients } \\
\text { Beta }\end{array}$} & \multirow[b]{2}{*}{$\mathbf{t}$} & \multirow[b]{2}{*}{ Sig. } \\
\hline & & B & Std. Error & & & \\
\hline \multirow[t]{3}{*}{1} & (Constant) & 3.300 & .090 & & 36.755 & .000 \\
\hline & Opini Audit & -.025 & .020 & -.104 & -1.276 & .204 \\
\hline & TemuanAudit & -34.867 & 15.381 & -.184 & -2.267 & .025 \\
\hline
\end{tabular}

Sumber : data diolah, 2020

Dari hasil uji-t dapat diperoleh persamaan sebagai berikut :

$$
\text { KINERJA }=3,300+-, 025(X 1)+-34,867(X 2)+e
$$

Berdasarkan table diatas dapat diartikan bahwa :

1. Variabel opini audit memiliki nilai thitung sebesar $-1,276$ dan tabel sebesar $-1,655$ sehingga nilai thitung lebih kecil dari nilai tabel. Nilai signifikasinya sebesar 0,204 >0,05. Hal ini menunjukkan bahwa opini audit tidak berpengaruh terhadap kinerja pemerintah daerah Kabupaten/Kota di Jawa Timur, dengan demikian $\mathbf{H}_{\mathbf{1}}$ ditolak.

2. Variabel Temuan Audit BPK memiliki nilai thitung sebesar -2,267 dan tabel sebesar 
$-1,655$ sehingga nilai thitung lebih besar dari nilai tabel. Nilai signifikasinya sebesar 0,025 $<0,05$. Hal ini menunjukkan bahwa Temuan Audit BPK berpengaruh terhadap kinerja pemerintah daerah Kabupaten/Kota di Jawa Timur, dengan demikian $\mathbf{H}_{2}$ diterima.

\section{PEMBAHASAN}

\section{Pengaruh Opini Audit Terhadap Kinerja Pemerintah Kabupaten/Kota di Jawa} Timur.

Pengaruh opini audit terhadap kinerja pemerintah daerah Kabupaten/Kota di Jawa Timur tahun 2014-2017 diketahui bahwa perolehan hasil perhitungan thitung sebesar $-1,276$ dan tabel $-1,655$ (thitung $>$ tabel) dengan nilai signifikasinya sebesar 0,204 >0,05 sehingga $\mathbf{H}_{1}$ ditolak, artinya opini audit tidak berpengaruh signifikan terhadap kinerja pemerintah daerah Kabupaten/Kota di Jawa Timur tahun 2014-2017.

Hal ini didukung oleh penelitian yang telah dilakukan oleh Muflihatin (2016:93) menunjukkan bahwa opini audit tidak berpengaruh terhadap kinerja pemerintah daerah. hal tersebut dikarenakan opini audit hanya menilai tata kelola keuangan yang terdapat dalam laporan keuangan pemerintah daerah, apakah laporan tersebut dibuat sewajarnya sesuai peraturan perundang-undangan atau tidak.

2. Pengaruh Temuan Audit BPK Terhadap Kinerja Pemerintah Kabupaten/Kota di Jawa Timur.

Pengaruh Temuan Audit BPK terhadap kinerja pemerintah daerah Kabupaten/Kota di Jawa Timur tahun 2014-2017 diketahui bahwa perolehan hasil perhitungan thitung sebesar -2,267 dan tabel $-1,655$ ( $t_{\text {hitung }}<t_{\text {tabel }}$ ) dengan nilai signifikasinya sebesar 0,025< 0,05 sehingga $\mathbf{H}_{1}$ diterima, artinya Temuan Audit BPK berpengaruh signifikan terhadap kinerja pemerintah daerah Kabupaten/Kota di Jawa Timur tahun 2014-2017.

Hal ini didukung oleh penelitian yang telah dilakukan oleh Sudarsana dan Rahardjo (2013:11) menyatakan bahwa tingkat kekayaan dan temuan audit BPK berpengaruh positif terhadap kinerja pemerintah daerah.

\section{KESIMPULAN DAN SARAN}

Penelitian ini mencoba untuk menguji secara empiris pengaruh Opini Audit dan Temuan audit BPK berpengaruh terhadap kinerja pemerintah daerah di Jawa Timur tahun 2014-2017. Berdasarkan hasil uji asumsi klasik tidak ditemukan variabel yang menyimpang, sehingga data yang tersedia telah memenuhi syarat untuk diuji dengan model Uji Determinasi.

Peneliti memberikan simpulan dari hasil analisis Uji t yang telah dilakakukan adalah sebagai berikut :

1. Opini Audit tidak berpengaruh terhadap kinerja pemerintah daerah di Jawa Timur. Hal ini didukung dengan nilai thitung sebesar -1,276 dan tabel sebesar -1,655 sehingga nilai thitung lebih kecil dari nilai tabel. Nilai signifikasinya sebesar 0,204 > 0,05 dengan demikian H1 ditolak.

2. Temuan Audit BPK berpengaruh terhadap kinerja pemerintah daerah di Jawa Timur. Hal ini didukung dengan nilai thitung sebesar -2,267 dan tabel sebesar -1,655 sehingga nilai thitung lebih kecil dari nilai tabel. Nilai signifikasinya sebesar 0,562 <0,05 dengan demikian $\mathbf{H}_{2}$ diterima.

Penelitian ini tentunya memiliki keterbatasan, oleh karena itu penulis memberikan saran sebagai berikut : 
1. Bagi pemerintah daerah, diharapkan dapat terus memperbaiki dan meningkatkan kinerja pemerintah daerah semaksimal mungkin, sehingga mampu menghasilkan kinerja pemerintah daerah yang lebih optimal.

2. Bagi penelitian selanjutnya, diharapkan dapat memperluas obyek penelitian dengan meninjau kinerja pemerintah Kabupaten/Kota pada Provinsi lainnya, sehingga nantinya diperoleh hasil penelitian yang dapat digeneralisasikan untuk kinerja pemerintah daerah di Indonesia. Selain itu juga dapat menambah variabel selain yang digunakan agar hasilnya dapat terdefinisi dengan lebih sempurna.

\section{DAFTAR PUSTAKA}

Agoes, Sukisno. (2014). Auditing Petunjuk Praktis Pemeriksaan Akuntan oleh Akuntan Publik. Jakarta : Salemba Empat.

Ayuningsih, Diyah. (2016). Pengaruh Size, Wealth, Leverage, Belanja Daerah Dan Intergovern-mental Revenue terhadap Kinerja Keuangan Pemerintah Daerah di Jawa Tengah. Skripsi : IAIN Surakarta.

Cheung, Hin Wah Chris., So, M.Y.L., Choi, C.U.F., and Chow, Fung Philip, 2019, The influence of SAR government performance on people's trust toward Central government: Implications for Hong Kong and Macau civic education, Asian Education and Development Studies, Vol. 8 Issue : 1, pp. 47-58.

Fan, Hui. (2012). Government performance auditing demand research based on the neoinstitutional economics. China Finance Review International. Vol. 2 Iss 2 pp. $100-$ 120.

Fassa, Marisa Nadya. (2018). Pengaruh Karakteristik Pemerintah Daerah Terhadap Kinerja Keuangan Pemerintah Daerah (Studi Empiris pada Pemerintah Daerah Kabupaten /Kota Di Provinsi Jawa Tengah Tahun 2014-2017). Skripsi : Universitas Muhamadiyah Surakarta.

Ghozali, Imam. (2013). Aplikasi Analisis Multivariete Edisi 8. Semarang : Badan Penerbit Universitas Diponegoro.

Halim, Abdul dan Abdullah, S., 2015, "Hubungan Dan Masalah Keagenan Di Pemerintah Daerah: Sebuah Peluang Penelitian Anggaran dan Akuntansi”, J. Akunt. Pemerintah

Hendriyani R. dan Tahar A., 2015, "Analisis Faktor-Faktor Yang Memengaruhi Tingkat Pengungkapan Laporan Keuangan Pemerintah Provinsi Di Indonesia," J. Bisnis dan Ekon.

Janjua, Altamash., Attique, Farrukh., Raza, Adil and Akbar, Waqar. (2018). Effective performance management of local governments in Khyber Pakhtunkhwa, Pakistan. International Journal of Productivity and Performance Management.

Kusuma, Priyan Madya. \& Kurniasih, Lulus. (2017). Pengaruh Opini Audit dan Karakteristik Pemerintah Daerah Terhadap Kinerja Pemerintah Kabupaen/Kota di Indonesia. EQUITY Jurnal Ekonomi, Manajemen, Akuntansi. Vol. 20, No.1, Januari-Juni 2017.

Lin, Ming-lan., Lee, Yuan-Duen and Ho., Tsai-Neng, 2010, Applying integrated EA/AHPto evaluate the economic performance of local governments in China, European Journal of Operational Research, 209 (2011) 129-140.

Maiyora, Gita. (2015). Pengaruh Karakteristik Pemerintah Daerah Terhadap Kinerja Keuangan Pemerintah Darah Kabupaten/Kota (Studi Empiris Kabupaten/Kota di Pulau Sumatera). Jom FEKON Vol. 2 No. 2.

Masdiantini, Putu Riesty dan Erawati, Ni Made Adi, 2016, "Pengaruh Ukuran Pemerintah Daerah, Kemakmuran, Intergovernmental Revenue, Temuan dan Opini Audit BPK Pada Kinerja Keuangan,” E-Jurnal Akuntansi Universitas Udayana.14 : 1150-1182.

Mardiasmo, 2009, Akuntansi Sektor Publik. Penerbit Andi, Yogyakarta. 
Moalla, Hanen and Baili, Rahma, 2019. Credit ratings and audit opinion: evidence from Tunisia. Journal of Accounting in Emerging Economies. Vol. 9 Issue: 1, pp. 103-125.

Muflihatin, A'alimatul. (2016). Pengaruh Opini Audit, Fungsi Pengawasan DPRD, dan Karakteristik Pemerintah Daerah Terhadap Kinerja Keuangan Pemerintah Daerah. Skripsi : Universitas Islam Negeri Syarif Hidayatullah Jakarta.

Mustikarini, Widya Astuti dan Debby Fitriasari. 2012. "Pengaruh Karakteristik Pemerintah Daerah Dan Temuan Audit Bpk Terhadap Kinerja Pemerintah Daerah Kabupaten/Kota di Indonesia Tahun Anggaran 2007'.Simposium Nasional Akuntansi XV: Banjarmasin.

Noviyanti, Nur Ade. \& Kiswanto. (2016). Pengaruh Karakteristik Pemerintah Daerah, Temuan Audit BPK Terhadap Kinerja Keuangan Pemerintah Daerah. AAJ 5 (1) Accounting Analysis Journal : Universitas Negeri Semarang.

Roh, Jongho, 2018, Improving the government performance management system in South Korea : Focusing on central government agencies. Asian Education and Development Studies. Vol. 7 Issue: 3, pp.266-278.

Samarinas, Panayiotis Tahinakis Michalis, 2016, The Incremental Information Content Of Audit Opinion. Journal Of Applied Accounting Research, Vol. 17 Iss 2 Pp.-.

Sudarsana, H. S., dan Rahardjo, S. N., 2013, Pengaruh Karakteristik Pemerintah Daerah Dan Temuan BPK Terhadap Kinerja Pemerintah Daerah. Diponegoro Journal of Accounting.

Sudrajat, M. A., dan Purniawati, Irma Diastuti, 2017, “Analisis Pengaruh PAD, DBH, DAU, DAK dan Pertumbuhan Ekonomi Terhadap Belanja Modal Kabupaten Ngawi Tahun 2003-2015. INVENTORY Jurnal Akuntansi Prodi Akuntansi-FEB UNIPMA, Vol.1, No.

Suhardjanto, D., dan Yulianingtyas, R. R., 2011, "Pengaruh Karakteristik Pemerintah Daerah terhadap kepatuhan Pengungkapan Wajib dalam Laporan Keuangan Pemerintah Daerah", J. Akunt. Audit. .

Suryaningsih N., dan Sisdyani, E., 2016, "Karakteristik Pemerintah Daerah Dan Opini Audit Pada Kinerja Keuangan Pemerintah Daerah", E-Jurnal Akuntansi Universitas Udayana Vol.15.2 : 1453-1481.

Sugiyono. (2017). Metode Penelitian Pendidikan. Bandung : Alfabeta.

Undang-Undang Republik Indonesia Nomor 23 tahun 2014 tentang Pemerintahan Daerah.

https://jatim.bps.go.id. Diakses pada tanggal 26 Januari 2019.

www.djpk.kemenkeu.go.id. Diakses pada tanggal 30 Januari 2019.

www.kemendagri.go.id. Diakses pada tanggal 4 Februari 2019.

www.surabaya.bpk.go.id. Diakses pada tanggal 6 Februari 2019.

Zelmiyanti, R., 2016, "Perkembangan Akuntansi Berbasis Akrual Pada Sektor Pemerintah Di Indonesia," JRAK. Febr.

Waliyyani, Amir, 2015. "Pengaruh Karakteristik Pemerintah terhadap Tingkat Pengungkapan Laporan Keuangan Pemerintah Daerah di Indonesia," Accounting Analysis Journal 4(2). 